\title{
IMPLIKASI DUALISME KETENTUAN RPJMD MENURUT PERATURAN PERUNDANG-UNDANGAN DIHUBUNGKAN DENGAN PRINSIP KEPASTIAN HUKUM
}

\author{
Zakki Saleh \\ Program Studi Magister Ilmu Hukum \\ Pascasarjana Universitas Islam Bandung \\ e-mail: zakres@yahoo.com
}

\begin{abstract}
Abstrak- Rencana Pembangunan Jangka Menengah (RPJM) adalah salah satu dokumen perencanaan pembangunan yang harus dirumuskan oleh pemerintah baik tingkat nasional maupun daerah. Namun, dalam praktiknya, ada dualisme peraturannya karena UndangUndang Nomor 25 Tahun 2004 tentang Sistem Perencanaan Pembangunan Nasional (UUSPPN) mengamanatkan untuk merumuskan RPJM dalam tiga bulan setelah presiden dan bupati terpilih. Sementara itu, Undang-Undang Nomor 23 Tahun 2014 tentang pemerintah daerah menetapkan bahwa RPJMD harus ditetapkan oleh peraturan daerah dalam jangka waktu 6 (enam) bulan setelah terpilihnya bupati. Hasil penelitian ini menunjukkan bahwa implikasi dari ketentuan dualisme tersebut melanggar prinsip hukum yaitu "lex specialis derogate lex generalis" karena ada ketidakharmonisan dan ketidakkonsistenan di setiap daerah saat merumuskan peraturan daerah.
\end{abstract}

Kata kunci: Dualisme, RPJM, RPJMD.

Abstract-Medium Term Development Plan (RPJM) is one of the development planning documents that are required to be formulated by the government either of national or regional level. However, in practice, there is a dualism of its rules as the Act Number 25 of 2004 on National Development Planning System (UUSPPN) mandates to formulate RPJM in three months after the president and the head of district have been elected. Meanwhile, the Act Number 23 of 2014 concerning local government provides that RPJMD shoul be stipulated by the regional regulation in the period of 6 (six) months after the elected the head of district. The result if this research indicates that the implication of such dualism provisions violates the principle of law i.e. "lex specialis derogate lex generalis" as there is disharmony and inconsistency in each region while formulating local regulations.

Keywords: Dualism, RPJM, RPJMD.

\section{A. PENDAHULUAN}

Rencana Pembangunan Jangka

Menengah (RPJM) merupakah salah

satu dokumen perencanaan

pembangunan yang diwajibkan

penyusunannya kepada pemerintah baik untuk tingkat nasional maupun tingkat daerah sesuai dengan UndangUndang Nomor 25 Tahun 2004 tentang Sistem Perencanaan Pembangunan Nasional selanjutnya 
Zakki Saleh, Implikasi Dualisme Ketentuan Rpjmd Menurut Peraturan Perundang-Undangan...

disebut UUSPPN (Sjafrizal, Pengendalian, dan Evaluasi

2014:317).

Undang-Undang tersebut mengamanatkan bahwa 3 (tiga) bulan setelah presiden dan kepala daerah dilantik penyusunan Rencana Pembangunan Jangka Menengah Nasional (RPJMN) dan Rencana pembangunan Jangka Menengah Daerah (RPJMD) harus sudah diselesaikan dan ditetapkan, untuk RPJMN ditetapkan dengan Peraturan Presiden dan RPJMD ditetapkan dengan peraturan Kepala Daerah. Namun demikian, kondisi tersebut ternyata dilapangan sulit direalisasikan, dengan munculnya aturan baru yaitu Undang-Undang Nomor 23 Tahun 2014 tentang Pemerintahan daerah yang selanjutnya disebut UU Pemda bahwa RPJMD ditetapkan dengan Perda. Perda tentang RPJMD ditetapkan paling lama 6 (enam) bulan setelah kepala daerah terpilih dilantik. Hal tersebut diatur dalam Peraturan Menteri Dalam Negeri (Permendagri) Nomor 54 tahun 2010 tentang Pelaksanaan Peraturan Pemerintah Nomor 8 Tahun 2008 Tentang Tahapan, Tatacara Penyusunan,
Pelaksanaan Rencana Pembangunan Daerah sebagai penjabaran dari UU Pemda. Aturan itu menyebutkan bahwa Peraturan Daerah tentang RPJMD provinsi dan Peraturan Daerah tentang RPJMD kabupaten/kota ditetapkan paling lama 6 (enam) bulan setelah kepala daerah terpilih dilantik dan RPJMD harus ditetapkan dengan Peraturan Daerah (Perda) yang ternyata memakan pembahasan yang cukup waktu.

Adanya perbedaan prosedur tentang penetapan RPJM antara ketentuan yang tertera dalam UU SPPN dengan UU Pemda. UU SPPN menyatakan bahwa RPJM ditetapkan dengan Peraturan Presiden (untuk nasional) dan Peraturan Kepala Daerah Untuk RPJM Daerah. Sedangkan pada Undang-Undang tentang Pemda, RPJM nasional harus ditetapkan oleh DPR dengan produk hukumnya Undang-Undang dan RPJMD oleh DPRD dengan produk hukumnya berupa Perda. Perbedaan ini tentunya, menimbulkan kebingungan bagi aparat perencana pembangunan baik ditingkat pusat 
Zakki Saleh, Implikasi Dualisme Ketentuan Rpjmd Menurut Peraturan Perundang-Undangan...

maupun tingkat daerah sehingga masyarakat daerahnya sendiri. perlu ada jalan keluar yang cukup Kewenangan membuat peraturan logis ditinjau dari segi prinsip ilmu daerah merupakan wujud nyata hukum maupun politik (Sjafrizal, pelaksanaan hak otonomi yang 2014:96).

Munculnya dualisme antara UU dimiliki oleh suatu daerah dan sebaliknya, peraturan daerah SPPN dan UU Pemda juga merupakan salah satu sarana dalam menimbulkan polemik tersendiri penyelenggaran otonomi daerah dalam pelaksanaannya di daerah. Dualisme ini menyulitkan daerah dalam menentukan sikap apakah akan mengacu pada UU SPPN atau UU Pemda sehingga menimbulkan disharmoni dan ketidakpastian hokum (http://birohukum.bappenas.go.id/ data/dakajian/kajiansewinduuu25t ahun2004).

Dalam penyelenggaraan otonomi daerah, ada dua produk hukum yang dapat dibuat oleh pemerintahan daerah, yaitu peraturan daerah dan peraturan kepala daerah.

Sehubungan dengan hal tersebut, dalam rangka mewujudkan kepentingan daerah yang berdasarkan pada aspirasi masyarakat, pemerintah daerah diberikan tanggung jawab yang besar dalam hal peraturan perundang-undangan dalam penyelenggaraan pemerintahan dan pembangunan untuk kepentingan

(Rozali Abdulllah, 2005:131).

RPJMD merupakan penjabaran visi, misi, dan program kepala daerah yang penyusunannya berpedoman kepada Rencana Pembangunan Jangka Panjang atau RPJP Daerah, dan memperhatikan RPJM Nasional, memuat arah kebijakan keuangan daerah, strategik pembangunan daerah, kebijakan umum, dan program satuan kerja perangkat daerah, lintas satuan kerja perangkat daerah, dan program kewilayahan disertai dengan rencana-rencana kerja dalam rangka regulasi dan kerangka pendanaan yang bersifat indikatif.

Pencapaian visi kepala daerah dilakukan secara bertahap melalui kinerja kepala daerah, yaitu gambaran mengenai tingkat pencapaian hasil pelaksanaan suatu program/ kegiatan/ kebijakan Pemerintah Daerah dalam 
Zakki Saleh, Implikasi Dualisme Ketentuan Rpjmd Menurut Peraturan Perundang-Undangan...

mewujudkan sasaran, tujuan, visi dan misi daerah yang tertuang dalam Dokumen Perencanaan Daerah. Dokumen Perencanaan Daerah dilihat dari dimensi waktu, terbagi atas Rencana Pembangunan Jangka Panjang Daerah 20 tahun (RPJPD), Rencana Pembangunan Jangka Menengah Daerah 5 (lima) tahun RPJMD dan Rencana Kerja Pembangunan Daerah satu tahun (RKPD). Berdasarkan atas dimensi waktu tersebut, kinerja pemerintah daerah dalam jangka panjang bertujuan untuk mencapai visi daerah.

Pencapaian visi daerah tersebut dilakukan secara bertahap melalui kinerja kepala daerah. Mengingat masa jabatan kepala daerah telah dibatasi untuk dua periode, maka visi kepala daerah periode pertama sampai periode ke empat yang tertuang dalam RPJP tidak boleh keluar dari visi daerah yang tertuang dalam RPJPD. Dengan cara demikian akan terjadi kesinambungan kebijakan, program dan kegiatan yang arahnya dan orientasinya terfokus kearah satu titik yakni tercapainya visi daerah. Hal demikian tidak berarti bahwa antara visi kepala daerah periode masa jabatan pertama harus sama dan sebangun dengan visi kepala daerah masa jabatan berikutnya.

Sebagamana diatur Pasal 263 UU Pemda, Dokumen perencanaan pembangunan Daerah terdiri atas RPJPD, RPJMD dan RKPD. RPJMD merupakan penjabaran dari visi, misi, dan program kepala daerah yang memuat tujuan, sasaran, strategi, arah kebijakan, pembangunan daerah dan keuangan daerah, serta program perangkat daerah dan lintas perangkat daerah yang disertai dengan kerangka pendanaan bersifat indikatif untuk jangka waktu 5 (lima) tahun yang disusun dengan berpedoman pada RPJPD dan RPJMN.

Berdasarkan Pasal 261 UU Pemda, pendekatan yang dilakukan dalam penyusunan perencanaan pembangunan daerah menggunakan pendekatan teknokratik, partisipatif, politis, serta atas-bawah dan bawahatas. Dalam penyusunan RPJMD, secara pendekatan politis dilaksanakan dengan menerjemahkan visi dan misi kepala daerah terpilih ke dalam dokumen perencanaan 
Zakki Saleh, Implikasi Dualisme Ketentuan Rpjmd Menurut Peraturan Perundang-Undangan...

pembangunan jangka menengah yang kemudian dibahas bersama dengan DPRD.

Berdasarkan Pasal 264 ayat (4) UU Pemda, RPJMD ditetapkan dengan Peraturan Daerah (Perda) paling lama 6 (enam) bulan setelah kepala daerah terpilih dilantik.

UU Pemda yang baru disahkan pada tanggal 30 September 2014 dan diundangkan pada tanggal 2 Oktober 2014 pada Lembaran Negara Republik Indonesia Tahun 2014 Nomor 244, Tambahan Lembaran Negara Republik Indonesia Nomor 5587, oleh karena itu berkaitan dengan penyusunan RPJMD Kabupaten Garut Tahun 2014-2019, dasar penyusunannya masih menggunakan Undang-Undang Nomor 32 Tahun 2004 (UU Pemda) yang lama.

Hal penting yang harus diperhatikan dalam menyusun rencana pembangunan daerah, sebagaimana diatur Pasal Pasal 67 huruf f UU Pemda, bahwa Kewajiban Kepala Daerah \& Wakil Kepala Daerah melaksanakan program strategis nasional. Sehubungan dengan telah ditetapkannya Peraturan
Presiden Nomor 2 Tahun 2015 tentang Rencana Pembangunan Jangka Menengah Nasional Tahun 2015-2019, maka RPJM Nasional tersebut selanjutnya menjadi bahan penyusunan dan penyesuaian RPJM Daerah dengan memperhatikan tugas dan fungsi pemerintah daerah dalam mencapai sasaran Nasional yang termuat dalam RPJM Nasional.

$$
\text { Sehubungan }
$$

RPJMD

Kabupaten Garut telah disusun dan ditetapkan sebelum RPJMN Tahun 2014-2019 ditetapkan, maka penyesuaian dan penyelarasan RPJMD terhadap RPJMN tersebut dilakukan secara bertahap setelah terlebih dahulu dilakukannya penyelarasan RPJMD Provinsi Jawa Barat Tahun 2013-2018 terhadap RPJMN Tahun 2015-2019 yang selanjutnya menjadi dasar penyelarasan RPJMD kabupaten/kota di Jawa Barat, termasuk RPJMD Kabupaten Garut terhadap kebijakan pembangunan jangka menengah Nasional. Pada saat penyelarasan RPJMD Kabupaten Garut Tahun 2014-2019 terhadap RPJMN Tahun 2015-2019 dilakukan, maka landasan penyusunannya disamping 
Zakki Saleh, Implikasi Dualisme Ketentuan Rpjmd Menurut Peraturan Perundang-Undangan...

berdasarkan UU Pemda yang lama yaitu Undang-Undang Nomor 32 Tahun 2004, juga berlandaskan pada UU Pemda yang baru yaitu UndangUndang Nomor 23 Tahun 2014 tentang Pemerintahan Daerah.

Berdasarkan permasalahanpermasalahan tersebut, di dalam kerangka penelitian ilmiah, penulis tertarik untuk melakukan penelitian lebih lanjut terhadap Implikasi Dualisme Ketentuan Tentang Rencana Pembangunan Jangka Menengah Daerah Menurut UndangUndang Nomor 25 Tahun 2004 Tentang Sistem Perencanaan Pembangunan Nasional dan UndangUndang Nomor 23 Tahun 2014 Tentang Pemerintahan Daerah Dihubungkan dengan Prinsip Kepastian Hukum.

Berdasarkan latar belakang sebagaimana telah diuraikan, maka dapat dirumuskan identifikasi masalah yang akan dianalisis dalam penelitian ini yaitu: bagaimana implikasi hukum dualisme bentuk pengaturan yang mengatur tentang Rencana Pembangunan Jangka Menengah Daerah (RPJMD) menurut Undang-Undang Nomor 25 Tahun
2004 tentang Sistem Perencanaan Pembangunan dihubungkan dengan Undang-Undang Nomor 23 Tahun 2014 tentang Pemerintahan Daerah? dan kedudukan hukum Peraturan Daerah Kabupaten Garut Nomor 3 Tahun 2014 tentang Rencana Pembangunan Jangka Menengah Daerah (RPJMD) tahun 2014-2019 dihubungkan dengan prinsip kepastian hukum?

\section{B. HASIL DAN PEMBAHASAN}

1. Implikasi Hukum Dualisme Bentuk Pengaturan RPJMD Menurut Peraturan

\section{Perundang-undangan}

\section{a. Komplikasi Perencanaan} Pembangunan

Sistem

Perencanaan

Pembangunan Nasional secara umum diatur dalam Undang-Undang Nomor 25 Tahun 2004 Tentang Sistem Perencanaan Pembangunan Nasiona, dirasakan adanya berbagai komplikasi dalam pelaksananaan pembangunan di daerah yang disebabkan oleh pelaksanaan demokratisasi otonomi daerah. Penerapan proses demokratisasi menyebabkan penyusunan pelaksanan 
Zakki Saleh, Implikasi Dualisme Ketentuan Rpjmd Menurut Peraturan Perundang-Undangan...

rencana pembangunan harus maupun tingkat nasional maupun dilakukan dengan lebih tingkat daerah harus sama yaitu memperhatikan keinginan dan 2005-2025. Sementara itu jadwal aspirasi masyarakat yang seringkali waktu Rencana Pembangunan berbeda satu antara daerah yang satu Jangka Menengah (RPJM) dengan daerah lainnya (Sjafrizal, disesuaikan dengan masa jabatan 2014:126). Sedangkan penerapan kepala daerah. Akibatnya, terjadinya otonomi daerah memberikan ketidak sinkronan atau komflik antara kewenangan lebih besar kepada jadwal waktu RPJPD dengan RPJMD pemerintah daerah untuk menentuan pada masing-masing daerah. Hal itu arah kebijakan pebangunan didaerahnya masing-masing. Hal ini menyebabkan timbulnya variasi yang sangat besar dalam penyusunan perencanaan pembangunan dimasingmasing daerah pasca Pemilihan Kepala Daerah atau Pilkada yang cenderung bervariatif sesuai dengan visi dan misi kepala daerah terpilih, hal menyebabkan koordinasi dan konsistensi dalam penyusunan perencanaan pembangunan daerah secara nasional menjadi sulit dilakukan.

\footnotetext{
Komplikasi lainya sebagai akibat penerapan prinsip otonomi daerah adalah menyangkut dengan jadwal waktu berlakunya perencanaan pembangunan. Berdasarkan UndangUndang Nomor 17 Tahun 2007 bahwa peride RPJP baik nasional
} membawa implikasi cukup besar terhadap keterpaduan dan sinkronisasi pembangunan baik anta pusat maupun daerah (Sjafrizal, 2014:127).

\section{b. Disharmoni Dualisme bentuk Pengaturan RPJMD}

Beberapa peraturan perundangundangan yang mengatur mengenai perencanaan baik di daerah dan di pusat antara lain, UU 23/2014, PP 8/2008, Permendagri 50/2010 yang mengatur mengenai perencanaan di daerah, dan PP 39/2006 yang mengatur Tata Cara Pengendalian dan Evaluasi Pelaksanaan Rencana Pembangunan, dan PP 40/2006 yang mengatur mengenai perencanaan nasional. Beberapa hal yang menunjukkan adanya disharmoni, 
Zakki Saleh, Implikasi Dualisme Ketentuan Rpjmd Menurut Peraturan Perundang-Undangan...

inkonsistensi dan pertentangan antar peraturan perundang- undangan tersebut. Adanya dualisme penetapan RPJMD antara UU SPPN dan UU Pemda menimbulkan polemik tersendiri dalam pelaksanaannya di daerah. Dualisme ini menyulitkan daerah dalam menentukan sikap apakah akan mengacu pada UU 25/2004 ataukah UU 23/2014.

Dualisme ini seperti sudah menjadi kesepakatan tidak tertulis bahwa untuk proses perencanaan di $\mathrm{K} / \mathrm{L}$ menggunakan UU SPPN sedangkan untuk di daerah menggunakan UU Pemda yaitu:

1) Adanya inkonsistensi pengaturan dasar hukum RPJMD

Dalam UU SPPN dan UU Pemda terjadi inkonsistensi mengenai dasar hukum penetapan RPJMD. Dalam UU 25/2004 Pasal 19 ayat (3) menyatakan bahwa RPJMD ditetapkan dengan Peraturan Kepala Daerah paling lambat 3 (tiga) bulan setelah Kepala Daerah dilantik, sementara berdasarkan UU Pemda Pasal 264 ayat (1) dan (4) bahwa RPJMD ditetapkan dengan Perda dan Perda tentang RPJMD ditetapkan paling lama 6 (enam) bulan setelah kepala daerah terpilih dilantik.

Menurut Purnadi Purbacaraka \& Soerjono Soekanto, ketidakharmonisan peraturan perundang-undangan timbul karena satu dan lain sebab, antara lain (Purnadi Purbacaraka \& Soerjono Soekanto, 1979:1519): pertama, Kebijaksanaankebijaksanaan antar instansi Pemerintah Pusat yang saling bertentangan; kedua, adanya perbedaan antara kebijaksanaan yang dikeluarkan oleh Pemerintah Pusat dan Pemerintah Daerah; ketiga, adanya rumusan ketentuan peraturan perundang-undangan yang kurang tegas atau jelas dan mengundang perbedaan penafsiran; dan keempat, benturan antara wewenang instansi-instansi pemerintah karena pembagian wewenang yang tidak sistematis dan jelas.

Menurut Oka Mahendra, disharmoni antar peraturan perundang-undangan terjadi karena (www.djp.kemenkumham.go.id): 
a) Pembentukan dilakukan oleh lembaga yang berbeda dan sering dalam kurun waktu yang berbeda;

b) Pejabat yang berwenang untuk membentuk peraturan perundang- undangan bergantiganti baik karena dibatasi oleh masa jabatan, alih tugas atau penggantian;

c) Pendekatan sektoral dalam pembentukan peraturan perundang- undangan lebih kuat dibanding pendekatan sistem;

d) Lemahnya koordinasi dalam proses pembentukan peraturan perundang-undangan yang melibatkan berbagai instansi dan disiplin hukum;

e) Akses masyarakat untuk berpartisipasi dalam proses pembentukan peraturan perundang-undangan masih terbatas;

f) Belum mantapnya cara dan metode yang pasti, baku dan standar yang mengikat semua lembaga yang berwenang membuat peraturan perundangundangan.

\section{Disharmoni peraturan}

perundang-undangan

mengakibatkan:
a) Terjadinya
penafsiran
perbedaan
pelaksanaannya;
b) Timbulnya ketidakpastian hukum;
c) Peraturan perundang-undangan dan efisien; tidak terlaksana secara efektif
d) Disfungsi hukum, artinya hukum tidak dapat berfungsi

memberikan pedoman berperilaku kepada masyarakat, pengendalian sosial, penyelesaian sengketa dan sebagai sarana perubahan sosial secara tertib dan teratur.

Sementara menurut Moh. Mahfud MD, Peraturan-peraturan perundang-undangan yang sejenis apabila mengatur materi yang sama, maka peraturan yang terbaru harus diberlakukan, walaupun tidak dengan secara tegas dinyatakan bahwa peraturan yang lama itu dicabut (Moh. Mahfud MD, 2007:127). Selain itu, peraturan yang mengatur yang lebih khusus harus diutamakan dari peraturan yang bersifat lebih umum.

Menurut Amiroeddin Sjarif (Amiroeddin Sjarif, 1997:78-84) bahwa Undang-undang yang dibuat oleh penguasa yang lebih tinggi, mempunyai kedudukan yang lebih tinggi pula; Undangundang yang bersifat khusus menyampingkan undang-undang yang bersifat umum (lex specialis derogate lex generalis); dan Undang-undang yang berlaku belakangan membatalkan undang- 
Zakki Saleh, Implikasi Dualisme Ketentuan Rpjmd Menurut Peraturan Perundang-Undangan...

undang yang berlaku terdahulu (lex posteriore derogate lex priori).

2) Adanya Konflik Norma Hukum

Sistem Hukum di Indonesia yang menghasilkan peraturan perundang-undangan selayaknya dapat berfungsi sebagai aturan dasar dalam kehidupan bernegara dan bermasyarakat. Namun pada kenyataannya peraturan perundang-undangan yang dibuat oleh pemerintah pusat dan daerah masih saja menimbulkan ketidakpastian dalam penegakan hukum. Kelemahan sistem hukum tersebut teridentifikasi tiga permasalahan yaitu karena tumpang-tindih dan inkonsistensi peraturan perundang-undangan dan Implementasi undang-undang yang terhambat peraturan pelaksananya serta tidak adanya peraturan perundang-undangan.

Dokumen Perencanaan

Daerah yang diatur dalam UU SPPN dan UU Pemda yaitu pendelegasian peraturan mengenai pengaturan lebih lanjut untuk mengatur tentang tata cara penyusunan dokumen perencanaan daerah seperti diatur dalam Pasal 27 ayat (2) UU SPPN "Ketentuan lebih lanjut mengenai tata cara penyusunan RPJP Daerah, RPJM Daerah, Renstra-SKPD, RKPD, RenjaSKPD dan pelaksanaan Musrenbang Daerah diatur dengan Peraturan Daerah".

Sementara Dalam UU Pemda Pasal 277:

"Ketentuan lebih lanjut mengenai tata cara perencanaan, pengendalian dan evaluasi pembangunan Daerah, tata cara evaluasi rancangan Perda tentang RPJPD dan RPJMD, serta tata cara perubahan RPJPD, RPJMD, dan RKPD diatur dengan peraturan Menteri”.

Kedua Pasal tersebut menurut peneliti terjadi tumpangtindih dan inkonsistensi peraturan perundang-undangan.

3) Perbedaan dalam Mekanisme Penyusunan Dokumen Perencanaan Daerah

Dalam penyusunan Dokumen Perencanaan Daerah juga mengalami perbedaan yang cukup signifikan. Dalam UUSPPN mekanisme penyusunan dokumen perencanaan daerah hanya dibuat 
Zakki Saleh, Implikasi Dualisme Ketentuan Rpjmd Menurut Peraturan Perundang-Undangan...

dalam mekanisme Musrenbang (Pasal 9 ayat (2) huruf c).

Sementara Dalam PP 8/2008, mekanisme penyusunan dokumen perencanaan daerah dapat melalui sistem Forum SKPD (Pasal 27 ayat (5)), Pembahasan \& Kesepakatan dengan DPRD (RPJMD) dan Musrenbang Daerah (Pasal 4 ayat (2) huruf b), sedangkan berdasarkan Inisiatif Daerah, mekanisme yang dapat dilakukan antara lain Pertemuan Pasca Musrenbang Daerah (Pasal 21) dan Dialog Interaktif Legislatif dan Eksekutif

(http://birohukum.bappenas.go.i d/data/dakajian/kajiansewinduu u25tahun2004).

4) RPJMN dan RPJMD kurang selaras

Selain pertentangan yang telah disebutkan diatas, ada pula yang menyebabkan disharmoni dokumen perencanaan, yaitu mengenai periodesasi RPJMD dan RPJMN yang tidak selaras dikarenakan perbedaan periode pilkada dan pilpres.
RPJMN yang berlaku sekarang ditetapkan dalam Perpres 2 tahun 2015, yang berlaku sejak tahun 2015 sampai dengan tahun 2019. Pemilihan Kepala Daerah tidak memiliki periodesasi yang sama dengan Pemilihan Presiden. Oleh karena itu setiap Kepala Daerah yang dilantik antara tahun 2010-2014 harus menyesuaikan RPJMD yang mereka miliki dengan RPJMN 2015-2019. Apabila ada penggantian Kepala Daerah pada interval tersebut maka RPJMD yang sudah ada harus disesuaikan kembali sehingga terjadi beberapa kali penggantian. Penyesuaian tersebut yang membuat RPJMD yang ada kurang sesuai dan kurang bersinergi dengan RPJMN yang ada.

5) Ketidaklengkapan Aturan Pelaksanaan dari UUSPPN

Bila dicermati kembali, sebenarnya masih ada beberapa aturan pelaksana yang perlu diatur lebih lanjut dari UUSPPN. Dalam ketentuan Pasal 27 UUSPPN ayat (1) dinyatakan bahwa "Ketentuan lebih lanjut 
Zakki Saleh, Implikasi Dualisme Ketentuan Rpjmd Menurut Peraturan Perundang-Undangan...

mengenai tata cara penyusunan RPJP Nasional, RPJM Nasional, Renstra-KL, RKP, Renja-KL, dan pelaksanaan Musrenbang diatur dengan Peraturan Pemerintah".

Apabila diamati kembali pada aturan pelaksana UUSPPN yang ada yaitu PP 39/2006 dan PP 40/2006, maka dapat ditemukan bahwa 2 (dua) Peraturan Pemerintah tersebut memang tidak mengamanatkan adanya aturan pelaksana yang lain. Namun meskipun tidak ada amanat dari peraturan perundang-undangan yang ada, Menteri PPN/Kepala Bappenas masih dapat mengeluarkan Peraturan Pelaksananya yang bisa berbentuk Peraturan Menteri atau bentuk lainnya. Dalam UUPPP dinyatakan bahwa Peraturan Menteri diakui dan mengikat sepanjang ada perintah aturan diatasnya atau berdasarkan kewenangannya.

\section{c. Munculnya Ego Sektoral Antar Lembaga}

Kendala dan permasalahan dalam pelaksanan harmonisasi hukum (peraturan perundang- undangan) di Indonesia dapat dirumuskan antara lain adalah

\section{(ditkumham.bappenas.go.id),}

sebagai berikut:

1) Masih adanya semangat egoisme sektoral atau departemental dari masing-masing instansi terkait, karena belum adanya persamaan persepsi (visi) tentang rancangan peraturan perundang-undangan sebagai suatu sistem sehingga pembahasan oleh wakil-wakil instansi terkait tidak bersifat menyeluruh tetapi bersifat fragmentaris menurut kepentingan masing-masing instansi. Sementara itu, Wakil-wakil yang diutus oleh instansi terkait sering berganti-ganti dan tidak berwenang untuk mengambil keputusan sehingga pendapat yang diajukan tidak konsisten, tergantung kepada individu yang ditugasi mewakili, sehingga menghambat pembahasan.

2) Tenaga fungsional Perancang Peraturan Perundang-undangan yang masih terbatas dan belum memiliki spesialisasi untuk menguasai bidang hukum tertentu, karena jabatan fungsional Perancang Peraturan Perundangundangantidak cukup menarik.

3) Belum ditetapkannya petunjuk teknis pengharmonisasian yang dapat dijadikan pedoman operasional dalam penyusunan dan pembahasan peraturan perundangundangan.

\section{d. Judicial Review}

Implikasi dualisme ketentuan bentuk peraturan RPJMD 
menimbulkan ketidakpastian hukum dan bertentangan juga dengan penerapan asas legalitas, menurut Indroharto, akan menunjang berlakunya kepastian hukum dan kesamaan perlakuan. Kesamaan perlakuan terjadi karena setiap orang yang berada dalam situasi seperti yang ditentukan dalam ketentuan undang-undang itu berhak dan bekewajiban untuk berbuat seperti apa yang ditentukan dalam undangundang tersebut. Kepastian hukum akan terjadi karena suatu peraturan dapat membuat semua tindakan yang akan dilakukan pemerintah itu dapat diramalkan atau diperkirakan lebih dahulu, dengan melihat kepada peraturan-peraturan yang berlaku, maka pada asasnya lalu dapat dilihat atau diharapkan apa yang akan dilakukan oleh aparat pemerintahan yang bersangkutan. Dengan demikian, warga masyarakat lalu dapat menyesuaikan dengan keadaan tersebut (Indriharto, 1993:83-84).

Menurut Burkens, rechtsstaat memiliki beberapa syarat dasar, diantaranya adalah asas legalitas: yaitu setiap tindakan pemerintahan harus didasarkan dasar aturan hukum (wettelikle grondslag). Dengan landasan ini, UU dan UUD sendiri merupakan tumpuan dasar tindak pemerintahan Pembentukan Undangundang merupakan bagian penting dari negara hukum (Philipus M. Hadjon, Tt:141). Agar terdapat kepastian hukum maka perorangan warga negara Indonesia, kesatuan masyarakat hukum adat, badan hukum publik atau privat atau lembaga negara, bisa melakukan judicial review atau pengujian Undang-Undang oleh UUD ke Mahkamah Konstitusi sebagaimana diamanatkan oleh Pasal 51 UU No 24 tahun 2003 tentang MK.

2. Kedudukan Hukum Peraturan daerah Kabupaten Garut Nomor 3 Tahun 2014 Tentang Rencana Pembangunan Jangka Menengah Daerah (RPJMD) Tahun 2014-2019

Dihubungkan Dengan Prinsip Kepastian Hukum

a. Tinjauan Kedudukan Hukum Peraturan Daerah

Pembentukan Perda adalah bentuk kewenangan delegasi kepada 
Zakki Saleh, Implikasi Dualisme Ketentuan Rpjmd Menurut Peraturan Perundang-Undangan...

Pemerintah Daerah untuk Sebagai Landasan Yuridis menyelenggarakan Otonomi Daerah Perda RPJMD bahwa bentuk dan tugas pembantuan sebagaimana peraturan daerah berdasarkan amanat Pasal 236 ayat (1) dan (2) ketentuan Pasal 150 ayat (3) huruf e UU Pemda bahwa untuk Undang-Undang Nomor 32 Tahun menyelenggarakan Otonomi Daerah 2004 tentang Pemerintahan Daerah dan Tugas Pembantuan, Daerah membentuk Perda. Perda sebagaimana dimaksud pada ayat (1) dibentuk oleh DPRD dengan persetujuan bersama kepala Daerah.

Mengenai kedudukan Perda Kabupaten/Kota dan Perda Provinsi bisa dilihat pada Pasal 7 ayat $1 \mathrm{UU}$ PPP. Jenis dan hierarki peraturan perundang-undangan terdiri atas:

1) Undang-Undang Dasar Negara Republik Indonesia Tahun 1945;

2) Ketetapan Majelis Permusyawaratan Rakyat;

3) Undang-Undang/Peraturan Pemerintah Pengganti UndangUndang;

4) Peraturan Pemerintah;

5) Peraturan Presiden;

6) Peraturan Daerah Provinsi; dan

7) Peraturan Daerah Kabupaten/Kota.

RPJMD Kabupaten Garut Tahun 2014-2019 RPJMD yang ditetapkan Bupati Kabupaten Garut Rudy Gunawan tertanggal 2 Juli 2014 mempunyai kedudukan hukum yang kuat. sebagaimana telah beberapa kali diubah, terakhir dengan Undangundang Nomor 12 Tahun 2008 tentang Perubahan Kedua Atas Undang-Undang Nomor 32 Tahun 2004 tentang Pemerintahan Daerah, Rencana Pembangunan Jangka Menengah Daerah (RPJMD) Kabupaten Garut Tahun 2014-2019 sebagaimana dimaksud dalam huruf a ditetapkan dengan peraturan daerah. Norma tersebut tidak menyalahi aturan yang berlaku dan telah dilaksanakan sesuai aturan yaitu UU Pemda yang lama (Undang-Undang Nomor 32 Tahun 2004).

Peraturan Daerah Kabupaten Garut Nomor 3 Tahun 2014 Tentang Rencana Pembangunan Jangka Menengah Daerah, RPJMD Kabupaten Garut Tahun 2014-2019 RPJMD ditetapkan Bupati Kabupaten Garut Rudy Gunawan tertanggal 2 Juli 2014. Sebagai Landasan Yuridis Perda RPJMD 
Zakki Saleh, Implikasi Dualisme Ketentuan Rpjmd Menurut Peraturan Perundang-Undangan...

bahwa bentuk peraturan daerah kerangka pendanaan yang bersifat berdasarkan ketentuan Pasal 150 ayat (3) huruf e Undang-Undang Nomor 32 Tahun 2004 tentang Pemerintahan Daerah sebagaimana telah beberapa kali diubah, terakhir dengan UndangUndang Nomor 12 Tahun 2008 tentang Perubahan Kedua Atas Undang-Undang Nomor 32 Tahun 2004 tentang Pemerintahan Daerah, Rencana Pembangunan Jangka Menengah Daerah (RPJMD) Kabupaten Garut Tahun 2014 - 2019 sebagaimana dimaksud dalam huruf a ditetapkan dengan peraturan daerah.

Berdasarkan Pasal 5 ayat (2) UUSPPN, RPJM Daerah merupakan penjabaran dari visi, misi, dan program Kepala Daerah yang penyusunannya berpedoman pada RPJP Daerah dan memperhatikan RPJM Nasional, memuat arah kebijakan keuangan daerah, strategi pernbangunan Daerah, kebijakan umum, dan program Satuan Kerja Perangkat Daerah, lintas Satuan Kerja Perangkat Daerah, dan program kewilayahan disertai dengan rencana-rencana kerja dalam kerangka regulasi dan indikatif.

Berdasarkan Penjelasan UU SPPN bahwa pendekatan politik memandang bahwa pemilihan Presiden/Kepala Daerah adalah proses penyusunan rencana, karena rakyat pemilih menentukan pilihannya berdasarkan programprogram pembangunan yang ditawarkan masing-masing calon Presiden/Kepala Daerah. Oleh karena itu, rencana pembangunan adalah penjabaran dari agenda-agenda pembangunan yang ditawarkan.

Sistem demikian mulai dilakukan di Indonesia sejak prinsip demokrasi diberlakukan dimana pemilihan presiden dan kepala daerah dipilih secara langsung oleh rakyat. Karena itu sesuai prinsip demokrasi, maka penyusunan perencanaan pembangunan dan pelaksanaannya dalam masyarakat nantinya harus juga berdasarkan janji kepala daerah yang disampaikan kepada masyarakat. Prinsip ini sesuai dengan amanat UU SPPN bahwa RPJMD adalah merupakan penjabaran lebih kongkret dari visi 
Zakki Saleh, Implikasi Dualisme Ketentuan Rpjmd Menurut Peraturan Perundang-Undangan...

dan misi kepala daerah terpilih (Sjafrizal, 2014:334).

\section{b. Ketidakpastian Hukum RPJMD Kabupaten Garut} tahun 2014-2019

Dalam penyusunan perda RPJMD Kabupaten Garut Tahun 2014-2019, selain beberapa peraturan perundang-undangan terkait yang menjadi landasan hukum namun masih menggunakan konsideran Undang-Undang Nomor 32 Tahun 2004 tentang Pemerintahan Daerah (Lembaran Negara Republik Indonesia Tahun 2004 Nomor 125, Tambahan Lembaran Negara Republik Indonesia Nomor 4437) sebagaimana telah beberapakali diubah, terakhir dengan UndangUndang Nomor 12 Tahun 2008 tentang Perubahan Kedua Atas Undang-Undang Nomor 32 Tahun 2004 tentang Pemerintahan Daerah (Lembaran Negara Republik Indonesia Tahun 2008 Nomor 59, Tambahan Lembaran Negara Republik Indonesia Nomor 4844) hal itu dikarenakan saat ditetapkan menjadi Perda UU Pemda yang baru belum diberlakukan.
UU Pemda baru disahkan pada tanggal 30 September 2014 dan diundangkan pada tanggal 2 Oktober 2014 pada Lembaran Negara Republik Indonesia Tahun 2014 Nomor 244, Tambahan Lembaran Negara Republik Indonesia Nomor 5587, oleh karena itu berkaitan dengan penyusunan RPJMD Kabupaten Garut Tahun 2014-2019, dasar penyusunannya masih menggunakan Undang-Undang Nomor 32 Tahun 2004.

Hal ini dikarenakan Bupati dan Wakil Bupati Garut periode 20142019 dilantik pada tanggal 23 Januari 2014, dan berdasarkan ketentuan Pasal 150 ayat (3) Undang-Undang Nomor 32 Tahun 2004 dan Pasal 15 Peraturan Pemerintah Nomor 8 Tahun 2008 tentang Tahapan, Tata Cara Penyusunan, Pengendalian dan Evaluasi Pelaksanaan Rencana Pembangunan Daerah, Peraturan Daerah tentang RPJMD ditetapkan paling lama 6 (enam) bulan setelah kepala daerah dilantik. Dalam hal ini telah ditetapkan Peraturan Daerah Nomor 3 Tahun 2014 tentang Rencana Pembangunan Jangka Menengah Daerah Kabupaten Garut 
Zakki Saleh, Implikasi Dualisme Ketentuan Rpjmd Menurut Peraturan Perundang-Undangan...

Tahun 2014-2019 pada tanggal 2 Juli 2014. Namun seiring dengan telah diundangkannya UU Pemda yang baru yaitu Undang-Undang Nomor 23 tahun 2014 yang disahkan tanggal 30 September 2014 dan diundangkan tanggal 2 Oktober 2014, maka kedudukan UU Pemda yang lama dicabut dan dinyatakan tidak berlaku.

Perberlakuan UU Pemda yang
baru menyebabkan beberapa
kewenangan Urusan Pemerintahan
kabupaten/kota dibagi menjadi
kewenangan pusat dan Provinsi.
Dalam Pasal 11 UU Pemda Urusan
pemerintahan konkuren yang menjadi
kewenangan Daerah terdiri atas
Urusan Pemerintahan Wajib dan
Urusan Pemerintahan Pilihan. Urusan
Pemerintahan Wajib terdiri atas
Urusan Pemerintahan yang berkaitan
dengan Pelayanan Dasar dan Urusan
Pemerintahan yang tidak berkaitan
dengan Pelayanan Dasar. Urusan
Pemerintahan Wajib yang berkaitan
dengan Pelayanan Dasar adalah
Urusan Pemerintahan Wajib yang
sebagian substansinya merupakan
Pelayanan Dasar.

Pemberlakuan UU Pemda ini menyebabkan beberapa kewenangan yang semula menjadi kewenangan kabupaten/kota kini dibagi menjadi kewenangan pemerintah provinsi dan pemerintah pusat. Dalam matriks pembagian Urusan Pemerintahan konkuren antara Pemerintah Pusat dan Daerah provinsi dan Daerah kabupaten/kota, untuk managemen pendidikan misalnya pengelolaan pendidikan menengah yang semula menjadi kewenangan pemerintah kab/kota dalam UU Pemda yang baru menjadi kewenangan pemerintah daerah provinsi.

Pasal 2 Peraturan Bupati Garut Nomor 385 Tahun 2014 tentang Rencana Kerja Pemerintah Daerah (RKPD) Kabupaten Garut tahun 2015 menyebutkan bahwa:

1) RKPD Kabupaten Garut Tahun 2015 merupakan penjabaran dari RPJMD Kabupaten Garut Tahun 2014-2019, serta disusun berdasarkan usulan-usulan program dan kegiatan hasil musyawarah Perencanaan Pembangunan.

2) RKPD Kabupaten Garut Tahun 2015 sebagaimana dimaksud pada ayat (1) berlaku untuk 1 (satu) tahun.

3) RKPD Kabupaten Garut Tahun 2015 sebagaimana dimaksud pada 
ayat (1) disusun dengan tujuan untuk menjadi pedoman bagi:

a) Penyusunan Rencana Kerja Satuan Kerja Perangkat Daerah (Renja- SKPD);

b) Penyusunan;

c) Kebijakan Umum Anggaran Pendapatan dan Belanja Daerah (KUA) serta Prioritas dan Plafon Anggaran Sementara (PPAS) Tahun 2015; dan

d) Penyusunan Rencana Anggaran Pendapatan dan Belanja Daerah (RAPBD) Tahun 2015.

Setiap peraturan perundangundangan harus memiliki dasar hukum pada peraturan perundangundangan yang lebih tinggi tingkatannya. Peraturan perundanganundangan tingkatan lebih rendah tidak boleh bertentangan dengan peraturan perundangan-undangan yang lebih tinggi. Apabila bertentangan maka hal itu dapat dituntut untuk dibatalkan bahkan batal demi hukum (van rechtwegenietig) (Bagir Manan, 2009:201).

Terkait dengan pembatalan perda RPJMD dalam Pasal 271 menyebutkan:

1) Evaluasi terhadap rancangan Perda Kabupaten/Kota tentang RPJMD yang dilakukan oleh gubernur sebagai wakil Pemerintah Pusat sebagaimana dimaksud dalam Pasal 267 ayat (2) dilaksanakan untuk menguji kesesuaian dengan RPJPD kabupaten/kota, RPJMD provinsi dan RPJMN, kepentinganumum dan/atau ketentuan peraturan perundang-undangan yang lebih tinggi.

2) Hasil evaluasi terhadap rancangan Perda Kabupaten/Kota tentang RPJMD sebagaimana dimaksud pada ayat (1) disampaikan gubernur sebagai wakil Pemerintah Pusat kepada bupati/wali kota paling lama 15 (lima belas) Hari sejak rancangan Perda diterima.

3) Apabila gubernur sebagai wakil Pemerintah Pusat menyatakan hasil evaluasi rancangan Perda Kabupaten/Kota tentang RPJMD tidak sesuai dengan RPJPD kabupaten/kota, RPJMD provinsi dan RPJMN, kepentingan umum dan/atau ketentuan peraturan perundangundangan yang lebih tinggi, bupati/wali kota bersama DPRD kabupaten/kota melakukan penyempurnaan paling lama 7 (tujuh) hari sejak hasil evaluasi diterima.

4) Dalam hal hasil evaluasi tidak ditindaklanjuti oleh bupati/walikotadan DPRD kabupaten/kota dan bupati/wali kota menetapkan rancangan Perda Kabupaten/Kota tentang RPJMD kabupaten/kota menjadi Perda, gubernur sebagai wakil Pemerintah Pusat membatalkan Perda dimaksud.

$$
\text { Untuk mengantisipasi }
$$

kekosongan dokumen perencanaan jangka menengah yang akan menjadi pedoman dalam penyusunan dokumen 
Zakki Saleh, Implikasi Dualisme Ketentuan Rpjmd Menurut Peraturan Perundang-Undangan...

Rencana Kerja Pemerintah Daerah

bahwa pada masa transisi, untuk (RKPD) Kabupaten Garut Tahun menghindari kekosongan, seperti 2015 maka menurut peneliti perlu disusun Rencana Pembangunan Jangka Menengah Daerah (RPJMD) Transisi Kabupaten Garut Tahun 2015 sebagai bagian yang tidak terpisahkan dari RPJMD Kabupaten Garut Tahun 2014-2019 yang memuat visi, misi, dan program Bupati dan Wakil Bupati Terpilih hasil pemilukada Kabupaten Garut Tahun 2013 serta merupakan kesinambungan dari RPJMD Kabupaten Garut Tahun 2009-2014 maka perlu disusun Rencana Pembangunan Jangka Menengah Daerah (RPJMD) Transisi Kabupaten Garut Tahun 2015 yang ditetapkan dengan Peraturan Bupati. Penjelasan atas Peraturan Pemerintah Nomor 8 Tahun 2008 tentang Tahapan, Tata Cara Penyusunan, Pengendalian dan Evaluasi Pelaksanaan Rencana Pembangunan Daerah. Penjelasan Pasal 40 ayat (2) huruf j PP 08 Tahun 2008 tentang Tahapan, Tata Cara Penyusunan, Pengendalian dan Evaluasi Pelaksanaan Rencana c. Kurang Selarasnya RPJMD dan RPJMN

Hal penting yang harus diperhatikan dalam menyusun rencana pembangunan daerah, sebagaimana diatur Pasal Pasal 67 huruf f UU Pemda, bahwa Kewajiban Kepala Daerah \& Wakil Kepala Daerah melaksanakan program strategis nasional. Sehubungan dengan telah ditetapkannya Peraturan Presiden Nomor 2 Tahun 2015 tentang Rencana Pembangunan Jangka Menengah Nasional Tahun 2015-2019, maka RPJM Nasional tersebut selanjutnya menjadi bahan penyusunan dan penyesuaian RPJM Daerah dengan memperhatikan tugas dan fungsi pemerintah daerah dalam mencapai sasaran Nasional yang termuat dalam RPJM Nasional.

Pembangunan Daerah, menyatakan 
Zakki Saleh, Implikasi Dualisme Ketentuan Rpjmd Menurut Peraturan Perundang-Undangan...

Sehubungan RPJMD

Kabupaten Garut telah disusun dan ditetapkan sebelum RPJMN Tahun 2014-2019 ditetapkan, maka penyesuaian dan penyelarasan RPJMD terhadap RPJMN tersebut dilakukan secara bertahap setelah terlebih dahulu dilakukannya penyelarasan RPJMD Provinsi Jawa Barat Tahun 2013-2018 terhadap RPJMN Tahun 2015-2019 yang selanjutnya menjadi dasar penyelarasan RPJMD kabupaten/kota di Jawa Barat, termasuk RPJMD Kabupaten Garut terhadap kebijakan pembangunan jangka menengah Nasional. Dan pada saat penyelarasan RPJMD Kabupaten Garut Tahun 2014- 2019 terhadap RPJMN Tahun 2015-2019 dilakukan, maka landasan penyusunannya disamping berdasarkan UUSPPN, juga berlandaskan pada UU Pemda.

\section{C.SIMPULAN}

1. Implikasi hukum adanya dualisme bentuk pengaturan RPJMD menurut UndangUndang Nomor 25 Tahun 2004 tentang Sistem Perencanaan Pembangunan dihubungkan dengan Undang-Undang Nomor 23 Tahun 2014 tentang Pemerintahan Daerah, bahwa dualisme bentuk pengaturan RPJMD ini melanggar asasasas perundang-undangan yaitu asas lex specialis derogate lex generalis. Akibatnya terjadi disharmoni dan inkonsistensi ditiap daerah saat membentuk peraturan daerah, menimbulkan ketidakpastian hukum dan dampak negatif terhadap penyatuan arah dan konsistensi pembangunan antara daerah dan pusat (nasional) atau antar masing-masing daerah sehingga keterpaduan, sinergitas, dan efisiensi proses pembangunan secara keseluruhan menjadi sukar diwujudkan.

2. Kedudukan hukum Peraturan Daerah Kabupaten Garut Nomor 3 Tahun 2014 tentang Rencana Pembangunan Jangka Menengah Daerah (RPJMD) tahun 2014-2019 adalah bentuk kewenangan delegasi, kepada Pemerintah Daerah untuk menyelenggarakan Otonomi Daerah dan tugas pembantuan 
sebagaimana amanat Pasal 236 ayat (1) dan (2) UU Pemda bahwa untuk menyelenggarakan Otonomi Daerah dan Tugas Pembantuan, Daerah membentuk Perda. Perda No. 3 tahun 2004 tentang RPJMD Kabupaten Garut 2014-2019 masih menggunakan konsideran Undang-Undang Nomor 32 tahun 2004 dan melanggar asas perundangan-undangan "Lex posterior derogat lege priori" atau aturan hukum yang lebih baru mengesampingkan atau meniadakan aturan hukum yang lama sehingga menimbulkan ketidakpastian hukum dan kekosongan hukum. Dengan diberlakukannya UU Pemda yang baru maka dalam urusan pemerintah menyebabkan beberapa kewenangan yang semula menjadi kewenangan kabupaten/kota kini dibagi menjadi kewenangan pemerintah provinsi dan pemerintah pusat.

\section{SARAN}

1. Untuk kepastian hukum dan tidak terjadi disharmoni produk perundang- undangan seperti bentuk peraturan RPJMD dalam UU SPPN dan UUPemda, maka perorangan warga negara Indonesia, kesatuan masyarakathukum adat, badan hukum publik atau privat atau lembaga negara, bisa melakukan Judicial review atau pengujian UndangUndang oleh UUD ke Mahkamah Konstitusi sebagaimana diamanatkan oleh Pasal 51 Undang-Undang Nomor 24 tahun 2003 tentang MK.

2. Dalam menciptakan Tata Kelola Pemerintahan yang Baik atau (Good Governance) yang mengharuskan suatu pemerintahan dikelola secara baik, benar dan penuh integritas, maka Perda Nomor 3 Tahun 2014 tentang RPJMD Kabupaten Garut Tahun 2014-2019 agar segera merevisi Perda dengan pijakan dasar hukum UU Pemda yang baru sehingga tercipta 
Zakki Saleh, Implikasi Dualisme Ketentuan Rpjmd Menurut Peraturan Perundang-Undangan...

kepastian hukum. Namun bila Perda tersebut dianggap bertentangan dengan kepentingan umum bisa dilakukan judicial review oleh perorangan warga negara Indonesia; kesatuan masyarakat hukum adat; atau badan hukum publik atau badan hukum privat.

\section{DAFTAR PUSTAKA}

Amiroeddin Sjarif, Perundangundangan: Dasar, Jenis dan Teknik Membuatnya, Rineka Cipta, Jakarta, 1997.

Bagir Manan, Menegakkan Hukum Suatu Pencairan, Asosiasi Advokat Indonesia, Jakarta, 2009.

Chabib Soleh, Suripto, Menilai Kinerja Pemerintahan Daerah, Fokus Media, Bandung, 2011.

Indriharto, Usaha Memahami Undang-undang Tentang Peradilan Tata Usaha Negara, Buku I, Sinar Harapan, Jakarta, 1993.

Moh. Mahpud MD., Membangun Politik Hukum, Menegakan Konstitusi, LP3ES, Jakarta, 2007.

Philipus M. Hadjon, Pelaksanaan Asas Kekuatan Berdasar atas Hukum (Rechtsstaat)

Dalam Kitab UU Hukum

Acara Pidana, Surabaya, Tanpa Tahun.

Purnadi Purbacaraka \& Soerjono Soekanto, Perundangundangan dan Yurisprudensi, Alumni, Bandung, 1979.

Rozali Abdulllah, Pelaksanaan Otonomi Luas Dengan Pemilihan Kepala Daerah Secara Langsung, PT. Raja Grafindo Persada, Jakarta, 2005.

Sjafrizal, Rencana Pembangunan Daerah Dalam Otonomi Daerah, Jakarta, Raja Grafindo Persada, 2014.

Undang-Undang Dasar 1945.

Undang-Undang Nomor 25 Tahun 2004 tentang Sistem Perencanaan Pembangunan Nasional.

Undang-Undang Nomor 17 Tahun 2007 tentang Rencana Pembangunan Jangka Panjang Nasional Tahun 2005-2025.

Undang-Undang Nomor 23 Tahun 2014 tentang Pemerintahan Daerah. 